\title{
Multiple Relationships of Maladjustment Schemas, Personality, and Family Relations with Alexithymia in Primary School Children
}

\author{
Elaheh Chalilorahman ${ }^{1}$, Zahra Yousefi ${ }^{* 2}$ \\ 1. M.A. in Clinical Psychology, Isfahan (Khorasgan) Branch, Islamic Azad University, Isfahan, Iran \\ 2. Assistant Professor, Department of Education \& Psychology, Isfahan (Khorasgan) Branch, Islamic Azad University, Isfahan, \\ Iran
}

Accepted: July 3, 2018

\begin{abstract}
Background and Purpose: Elementary school years are among the most important stages of development, as many of the child's capabilities, including emotional expressiveness, are developed during this period. Therefore, the present study was conducted with the aim of investigating the multiple relationships between maladjustment schemas, personality, and family relations with alexithymia.

Method: The present study was correlational. The sample consisted of 220 mothers with primary school children in Isfahan in the academic year of 2016-2017 who were selected through available sampling. The research tools consisted of five factor factors questionnaire (Costa and McCrae, 1992), short form of maladjustment Schema (Welbler et al., 2002), family relations (Barnes, 1982), and researcher developed alexithymia scale. Collected data were analyzed by Pearson correlation and stepwise regression.

Results: The results showed that the five domains of overvigilance and inhibition $(\mathrm{p}<0.001)$, impaired function $(\mathrm{p}<0.011)$, impaired autonomy and performance $(\mathrm{p}<0.001)$, other-directedness $(\mathrm{p}<0.011)$, and disconnection and rejection $(\mathrm{p}<0.001)$ had significant positive correlations with alexithymia, but there were no significant relations between other variables and alexithymia. Also, among the early maladjustment schemas, overvigilance and inhibition, autonomy, and impaired function of mothers can predict alexithymia among children.

Conclusion: As a result, it can be said that maladjustment schemas cause negative state among mothers that can intensify alexithymia among their children.
\end{abstract}

Keywords: Maladjustment schemas, personality, family relations, alexithymia, primary school children

Citation: Chalilorahman E, Yousefi Z. Multiple relationships of maladjustment schemas, personality, and family relations with alexithymia in primary school children. Quarterly Journal of Child Mental Health. 2019; 6(1): 124-137.

*Corresponding author: Zahra Yousefi, Assistant Professor, Department of Education \& Psychology, Isfahan (Khorasgan) Branch, Islamic Azad University, Isfahan, Iran.

Email: Psy.fa93@gmail.com

Tel: (+98) 9175967407 


\title{
روابط جند كانه روانبنههاى سازشنايافته اوليه، روابط خانوادگى، و شخصيت مادر با ناكويى هيجانى كود كان دبستانى
}

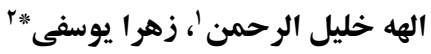 \\ ا. كارشناس ارشد روان شناسى بالينى، واحد اصفهان (خوراسكان)، دانشكاه آزاد اسلامى، اصفهان، ايران

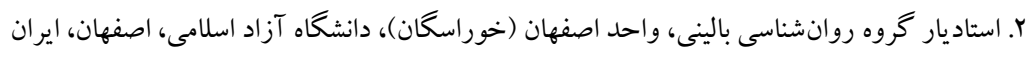

تاريخ بذيرش:

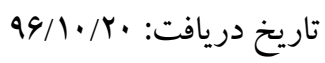

\section{جִكيده}

زمينه و هدف: سـالهاى دبسـتان يكى از مهمترين دورههاى تحول اسـت، جون بسـيارى از قابليت هاى كودك از جمله ابراز گرى

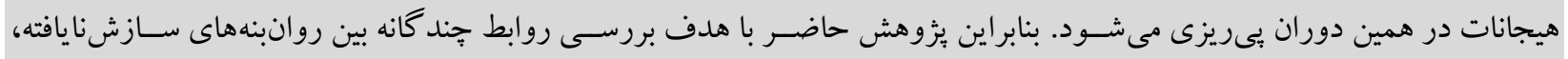

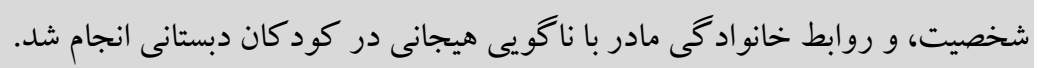

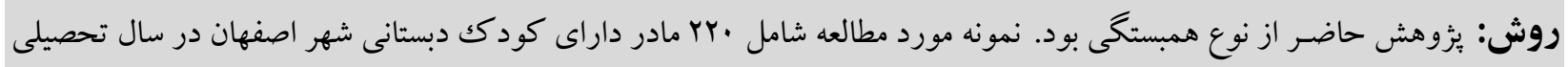

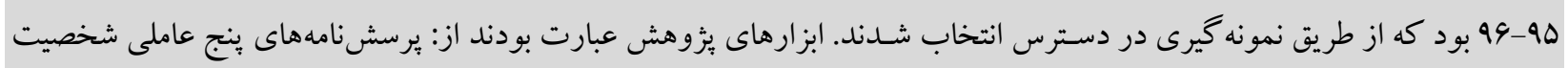

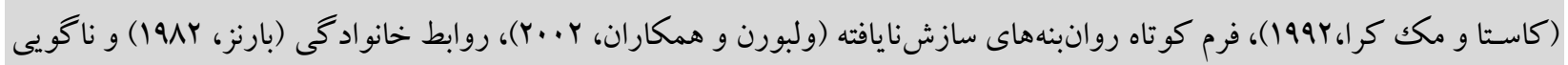

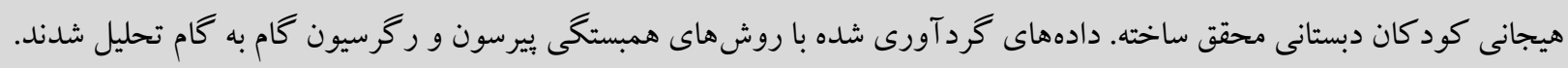

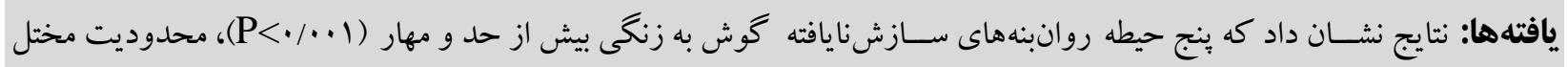

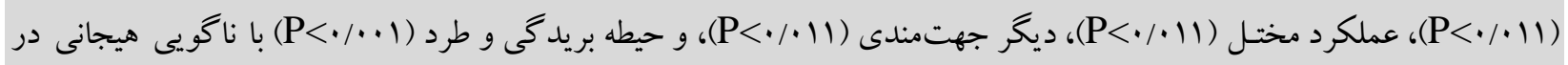

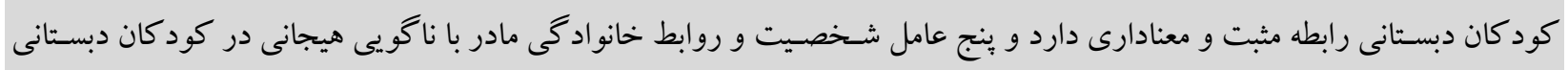

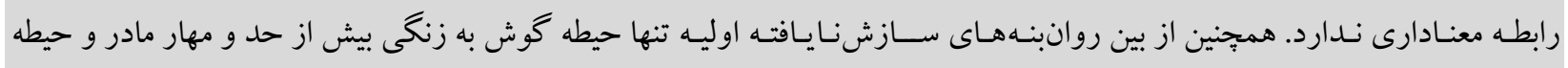
خود گردانى و عملكرد مختل مادر، توان بيش بينى ناگويى هيجانى در كود كان دبستانى راد داشته است.

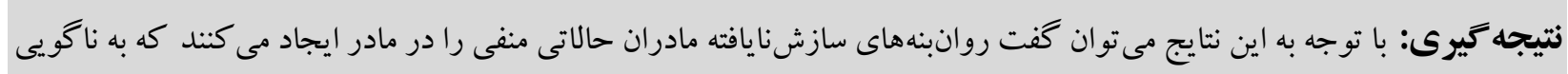
هيجانى در كود كان آنان دامن مىزند. كليدوازهها: روانبنهاى سازشنايافته، شخصيت، روابط خانوادگى، ناكويى هيجانى، كود كان دبستانى

*نويسنده مسئول: زهرا يوسفى، استاديار گروه روانشناسى بالينى، واحد اصفهان (خوراسكان)، دانشكاه آزاد اسلامى، اصفهان، ايران. تلفن: 99. ايميل:Z.yousefi@khuisf.ac.ir 
توسـ نارسـايى در خيال يردازى در كك مىشـود، و F) سـبكك

مقدمه

شناختى با جهت گيرى بيرونى.

كارشناسان كودكك و خانو اده همخى براين باورند كه يكى از

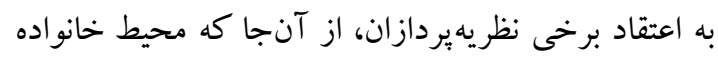

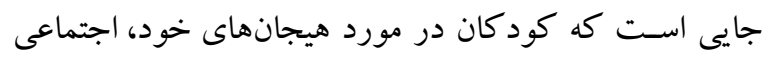

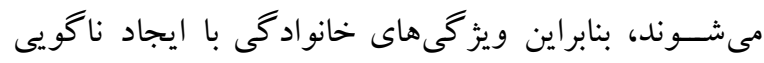

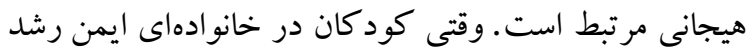
مى كنند و در بيان هيجانها حمايت مىشـوند، مى آموزند كه بهـ

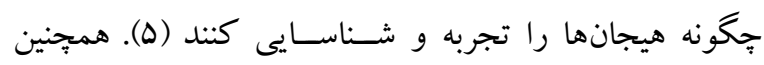

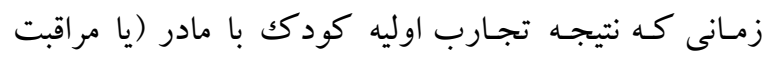
كنندهاى) به صـورتى باشـــ كه كودك هيجانهايش را ابراز نكند و در رابطه با احسـاسـاتش صحبت نكند و يا اين كه مادر در رابطه با تحول هيجانهاى كودك،، دانش كافى نداشـته

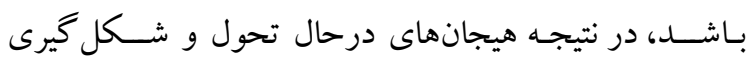

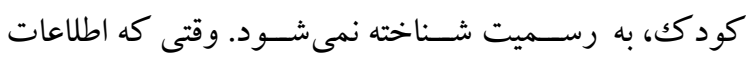

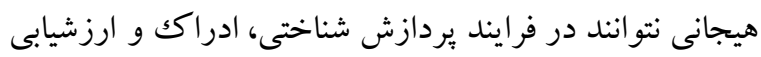

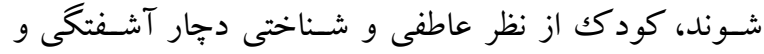
درماندكى مى شـود. با توجه به آن كه كودكى ســن مهمى از

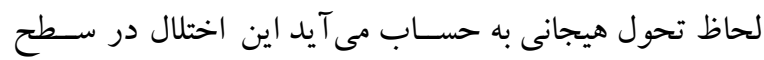

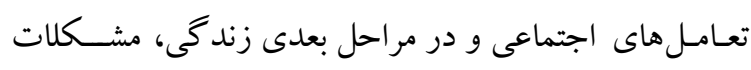
بينشخصى را بر او تحميل مى كند (9). در نتيجه لازم است تا

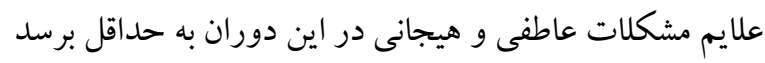

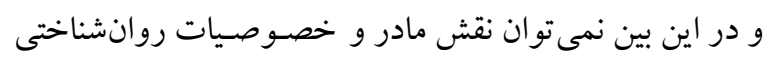
وى را ناديده كرفت

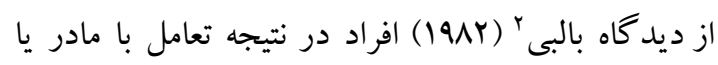

مراقبـت كنتـدهاى دوران كودكى خود به انتظاراتى درباره روابط اجتماعى و تجسـمهايى از خود در رابطه با افراد مهم

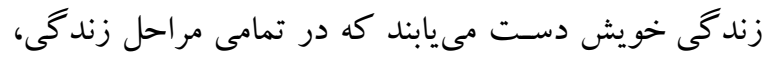

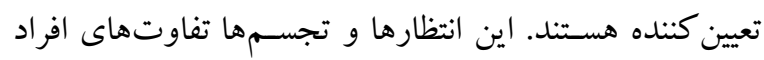
را در سـه زمينه اصلى نشان مىدهند: () باورهاى افراد درباره

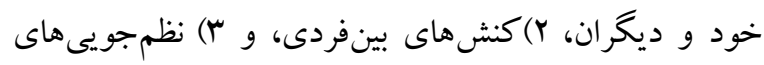
هيجانى و عاطفى. بنابر اين سـلـامت جســمانى و روانى مادر به به

يكى از كار كردهاى مهم هيجانها، كنار آمدن سازش يافته

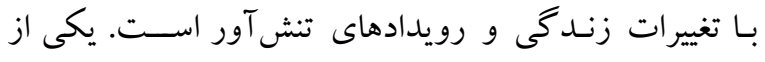
روشهـاى مهار تنش به خصــوص در مورد هيجانهاى منفى،

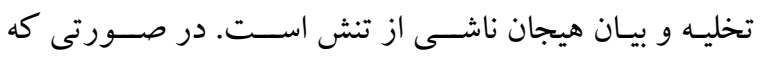

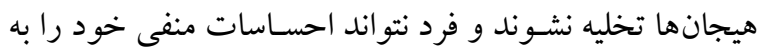
صـورت كلامى بيان كند بريشـانى روانى افزايش مى يابد و به

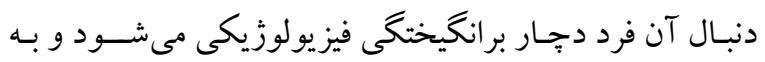

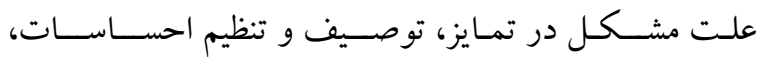

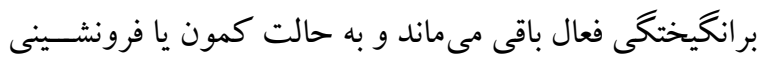

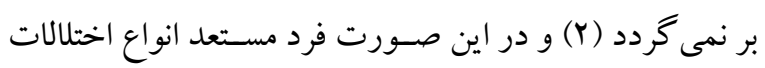
روانشـناختى و جسـمى مى شـود. برعكس افر ادى كه توانائى شـناخت احساسات خود را دارند و حالت هاى هيجانى خود را

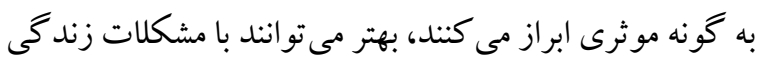

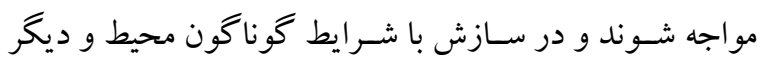
افراد، موفقترند كه در نتيجه اين افراد از سلامت روانى بيشترى

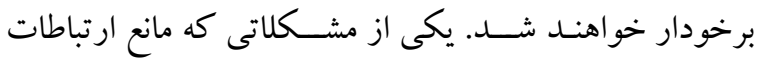

مناسب در اين دوران مىشود، ناكويى هيجانى ' است (r).

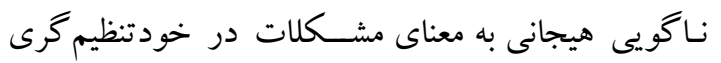

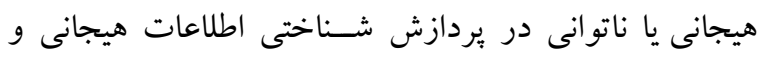

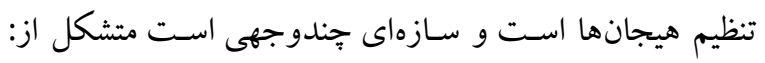
() دشـوارى درشناسايى و توصيف احساسات، Y) دشوارى در

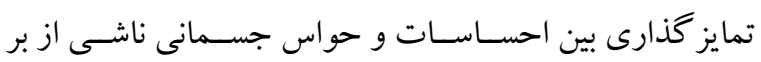
انخيختكى هيجـانى، (r) محدوديت در بردازش تصــورى ، كه 
بـا توجـه بـه اين كه بيشــر عمر يكك انســان درون محيط خـانو اده يا در ارتباط نزديكك با آنها ســـرى مى شــو، بنابر اين خصسوصسيات خلقى، هيجانى و شـيوههاى تربيتى والدين بر تحول شــــاختى، عـاطفى يـا رفتـارى كودك تـأثير دارد. مطالعات نشان مىدهند كه رفتار كود كان با شيوهاى رفتارى والدين به ويزه مادر، همبستخى زيادى دارد ( •او ل11).

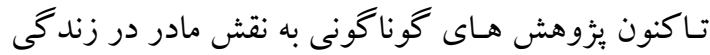

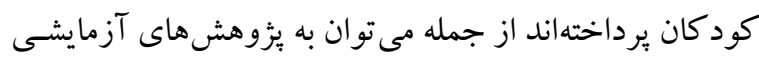

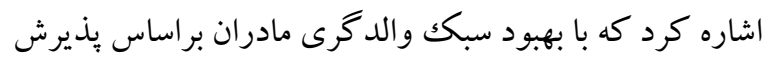
و تعهد (Y ا و rاI) به اصلاح حالات مادر و كودك يرداختهاند

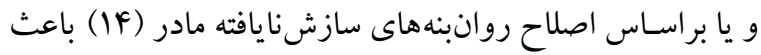

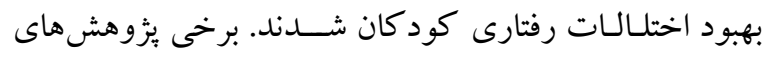
همبستخى نشان مىدهند ويزً گیى هاى مادران با حالات كود كان رابطه دارد، از جمله مى توان به رابطه خردمندى مادر با كاهش

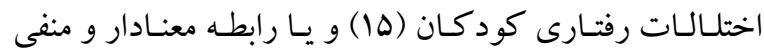

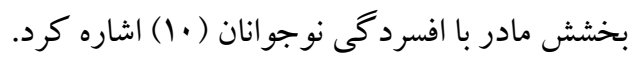

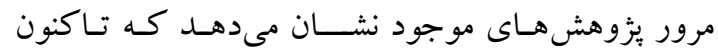

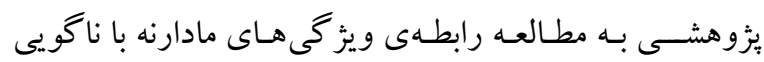
هيجانى نبرداخته اسـت و با توجه به اين كه سـالهاى دبســان

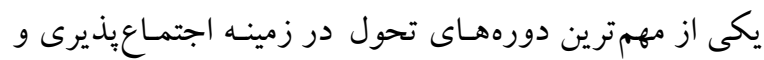

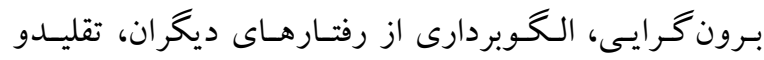
ابراز گرى هيجانات است بنابر اين ناكويى هيجانى مى تواند مانع مهمى در مسير تحول كودك باشد و هر گونه درمان آن نيازمند

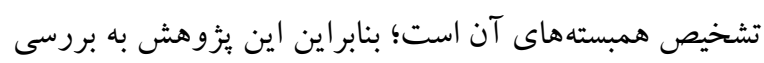

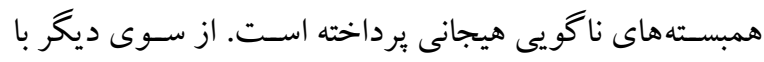

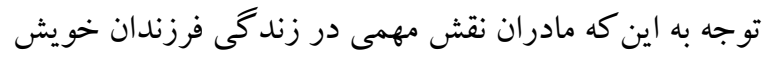

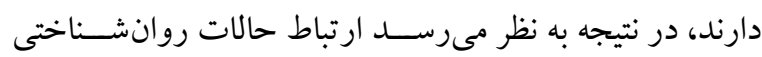
مادر با ناگويى هيجانى كودكك قابل بررسى است و نتايج جنين

7. Impaired autonomy and/or performance

8. Other-Directedness

9. Overvigilance/Inhibition
عنوان بزرگترين منبع امنيـت روانى و جســمانى در خانو اده از بنيادى ترين عو امل شكل گيرى شخصيت كودك است (ه). در اين ميـان روش تربيتى مـادر متـأثر از ويزز گیىهـا و حسالـات روانشــناختى او اســت (V) ويز كى هاى شــخصـيت مادر، روانبنهاى ســازشنايافته و روابط خانوادگى او از جمله اين ويز گیى ها مى تواند باشد.

مدل ينج عاملى شـــصـيت از جمله كاملترين مدلها اســت كه شــصــيت افراد را به ينج بعد تقسـيم مى كند:

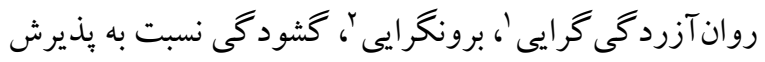

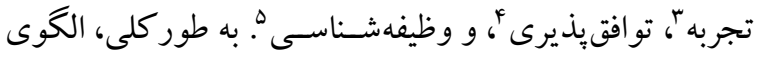
ينج عامل شــخصـيت، به عنوان مقياس ســنش ســـك هاى هيجانى، ارتباطى، و انخيزشسى افراد معرفى شـده اسـت (N). به نظر مىرسد ويز گى هاى شخصيت در شكل گيرى روانبنهاى ســازشتـايافته موثر اســـت. روانبنه ها عناصــر نظاممندى از واكنش ها و تجارب كذشـته هسـتند كه بيكره نسـبتاً منسـجم و يـايدارى از دانش را شـكل مىدهند كه مىتوانند ادارككها و ارزيـابىهـاى بعـدى را هـدايـت كنند. يكى از نظريه ها در اين زمينه نظريه روانبنه هاى سـازشنايافته اوليه يانگك اسـت. يانگك در نظريسه خود بـانزده طرحواره را معرفى كرده اســت كه در نتيجه ارضــا نشـــن بنج نياز هيجانى مهم بهو جود مى آيند: () بـريسـى و طرد

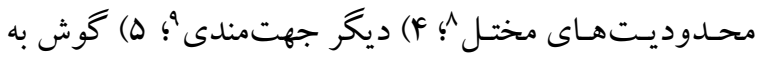
زنكى بيش از حد و باز دارى ". روانبنه هاى سـازشنايافته، در دوران كودكى يا نوجوانى شـكل گر فتهاند، در مسـير زندكى تداوم دارند و به شدت ناكار آمدند، موجب سو گيرى در تفسير از رويدادها مىشـوند، و به صسورت سـوء تفاهمها، نـخرشهاى تحريف شــده، و گمانهاى نادرسـت، خود را نشــان مىدهند

\footnotetext{
1. Neuroticism

2. Extraversion

3 .Openness

4. Agreeableness

5. Conscientiousness

6. Disconnection/Rejection
} 


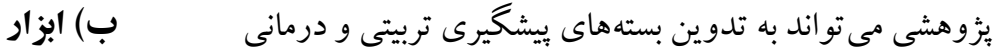

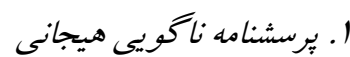

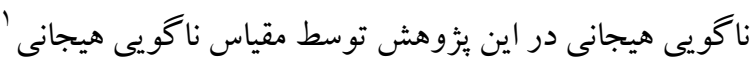

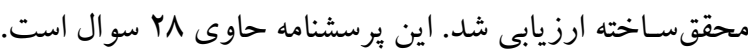

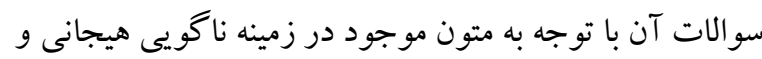

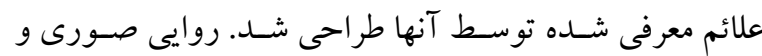

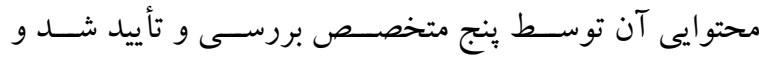

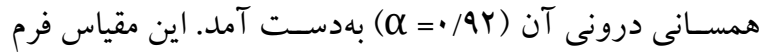

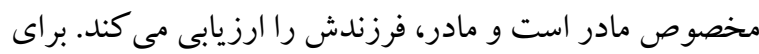

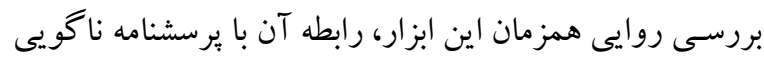

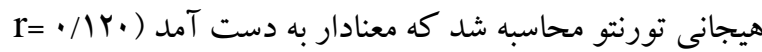

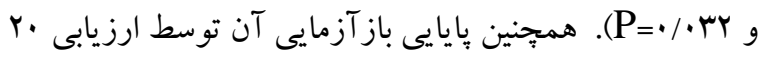

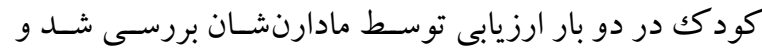

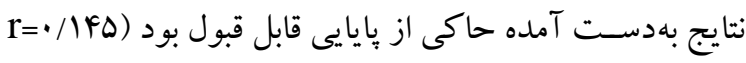

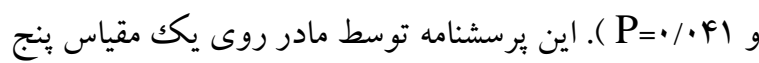

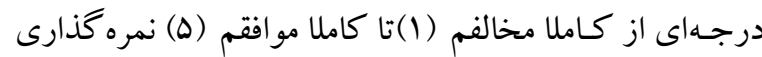

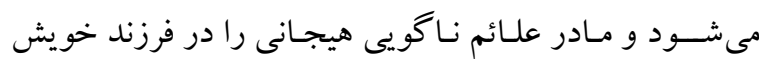

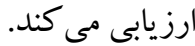
r. برسش نامه سنجش روابط خانوادكى بارنز

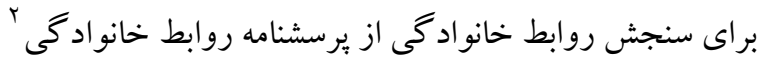

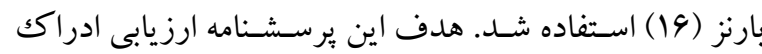
فرد از نوع روابطى اســت كـه بـا افراد خـانوادهاش دارد. اين

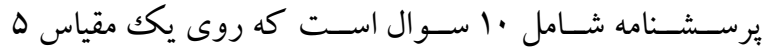

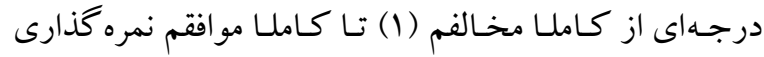

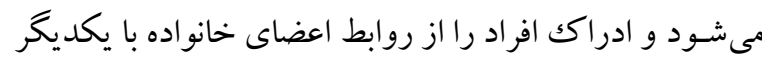

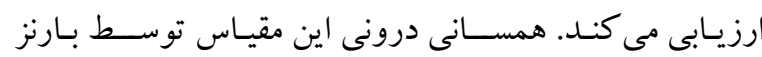

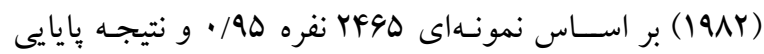
باز آزمايى צ^/ • گز ارش شده است. همجنين روايى محتوايى و همخراى آن بررسى و تأييد شـده است (19). در اين يزوهش

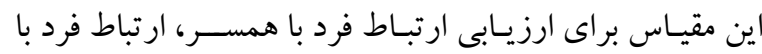

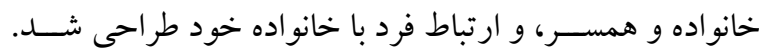

براى كودكان مبتلا به ناكويى هيجانى و حتى از منظرى ديخر

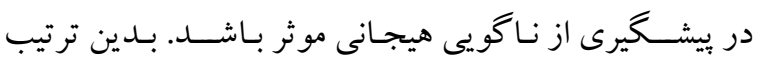
يُوهش حاضـر در صـدد ياسخ هاى به اين سوال انجام شد كه

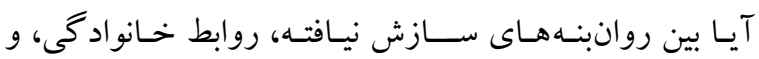

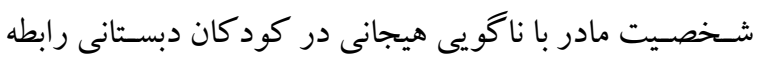

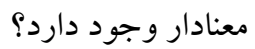

\section{روش} الف) طرح بزوهش و شـــــت كنند كان: با توجه به اين كه

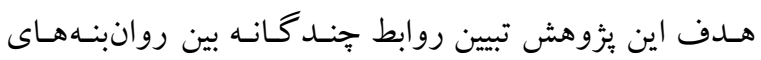

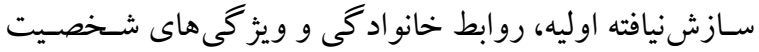
مـادر با ناكويى هيجانى در كود كان دبسـتانى بود و دادههاى

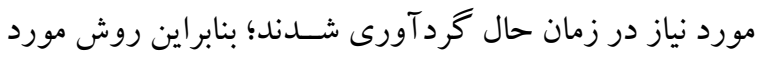
استفاده در اين يززوهش از نوع كمى، توصيفى و همبستخى بود. جامعه آمارى يُزوهش حاضـر شـامل تمامى مادران داراى كودكك دبستانى شـهر اصفهان در سـال تحصيلى هو-9 هو بود. نمونه مورد مطالعه شـامل • ب مادر از جامعه مذكور بود كه از طريق نمونه گيرى در دسـترس انتخاب شـدند. با توجه به اينكه

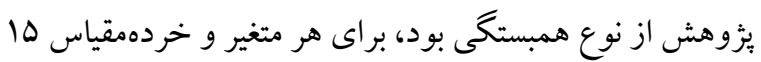

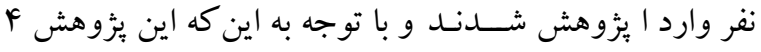
متغير و Y اخردهمتغير داشـت در كل •r مادر به عنوان نمونه

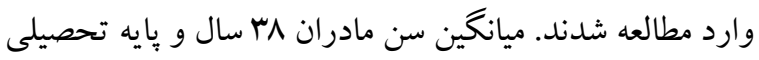

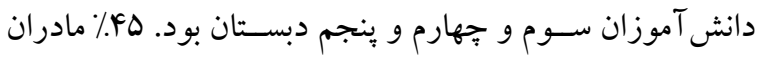

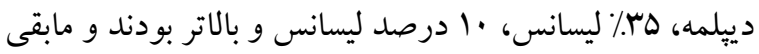
آنان زير دييلم و يا تحصيلاتشان نامشخص بود. معيارهاى ورود به يُزوهش عبارت بودند از: رضايت كامل مـادران كود كـان دبســــانى، حـداقل تحصــيلات للازم ســوم

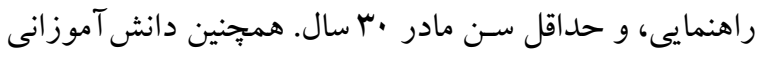
كه از اختلال هاى رفتارى هيجانى شـديد رنج مى بردند از نمونه

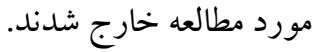


در ايران همسانى درونى آن توسط صدوقى، آكيلار - وفايى، رســولزاده طباطبائى و اصــهانيان (YI) در بين دانشـجويان

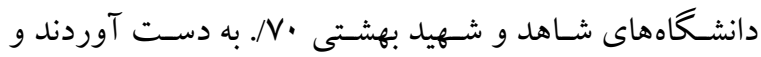
روايى ســازه آن را بـه كمـك تحليل عاملى بررسـى و تاييد

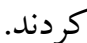
F. برسشنامه ينج عامل بزركك شخصيت

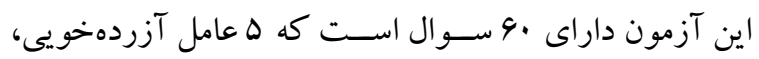

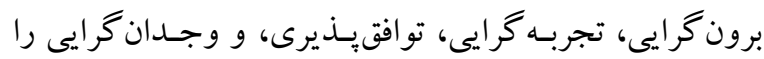

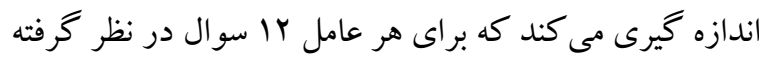

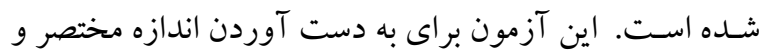
مفيدى از ها عامل شـخصـيت سـاخته شـــه اسـت (م). نحوه پاسـخ گويى به سـوالات به اين ترتيب است كه آزمودنى باسخ

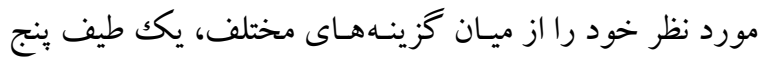

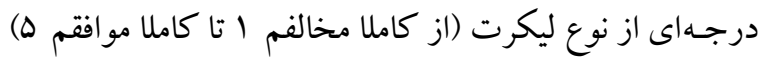

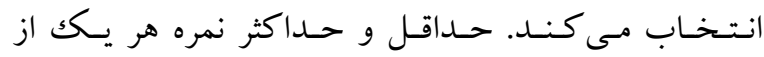
خردهمقياسها به ترتيب rا و .9 اسـت. مكك كرى، كاسـتاو و

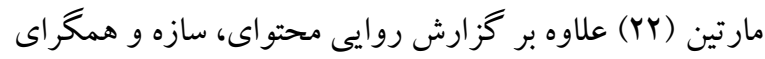

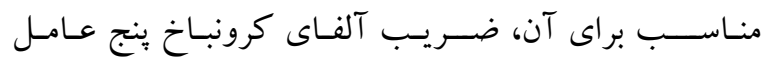

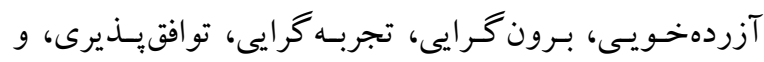

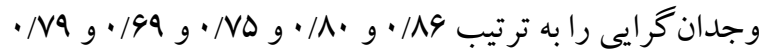
كزارش كردند. انيسى (r) در يكك جمعيت دانشجويى روايى

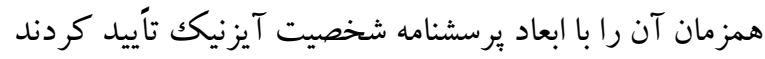
همجِين همسانى درونى آن را براى ابعاد مختلف •و/ • و بالاتر

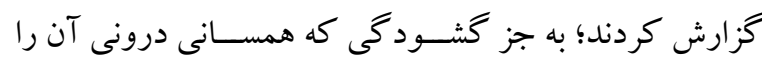

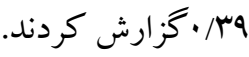

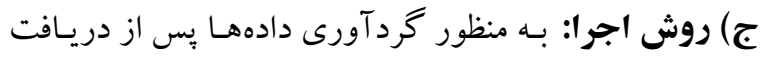

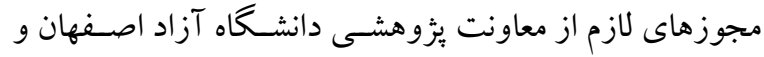

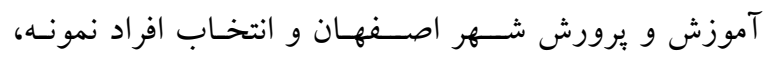
برسشنامه ها به همر اه دستور العمل راهنماى تكميل در جلسات

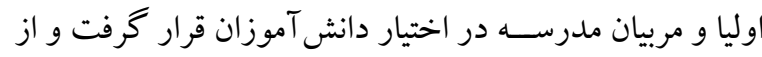
آنان خواسته شد پِ از تكميل برسشنامهها، به معلم فرزندشان

2. Five Factor Inventory (NEO)
يرســـنامه ارتباط فرد با همسـر، رابطه بين زن و شوهر را نشان مىدهد. مثال: (من و همسـرم از نحوه ارتباطى كه با هم داريم راضى هستيم). مقياس ارتباط فرد با خانو اده همسر، رابطه بين

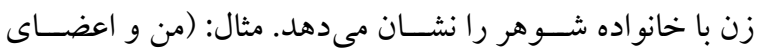

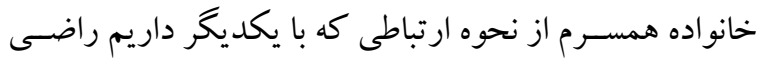

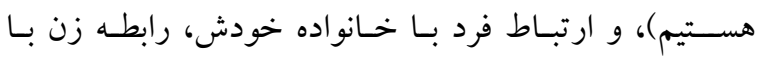
خانو ادهاش را ارزيابى مى كند. مثال: (من و اعضــاى خانو ادهام

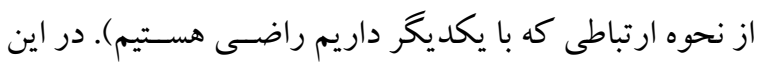
يرسشنامه نمره كل مورد نظر است. شماعىزاده و يوسفى( IV) همسـانى درونى اين يرسـشــنامه را براى ارتباط فرد با همسـر

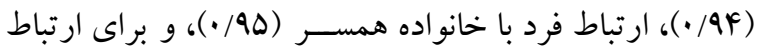
فرد بـا خـانواده خودش (91/91) به دسـت آورد كه قابل قبول

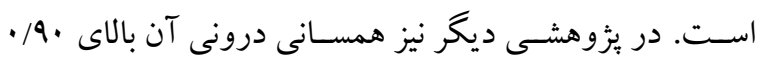

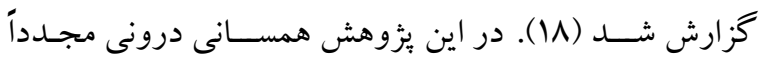
بررسى شد كه مقدار قابل قبول 9ه4/ بهدست آمد. "ا. برسشنامه روانبنه هاى سازشنا يافته هاى اوليه

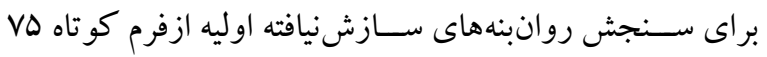
سـوالى برسـشـنامه روانبنهاى سازش رونيافته اوليه' استفاده شد.

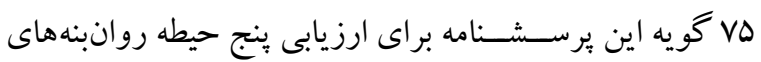

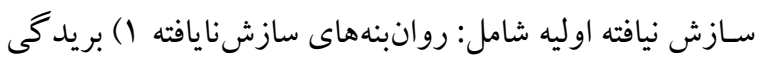

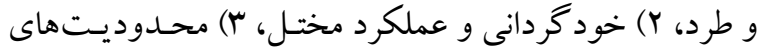
مختل، F) ديخرجهت مندى، و ه) گوش به زنكى بيش از حد و

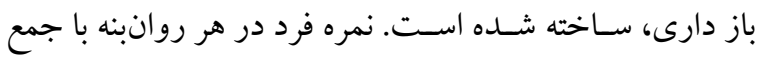

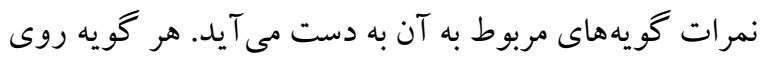
مقيـاس ه درجسهاى (ا كـاملـا مخـالفم و ه كـاملـا موافقم) نمره گذارى مى شـود. در اين ابزار هر هـ گويه، يكك روانبنه را

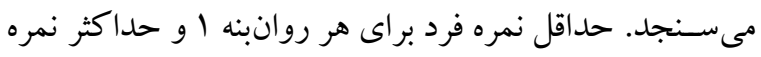
هr اسـت. اسـكميت، جوينر، يانگك و تلج (1990) روايى سازه

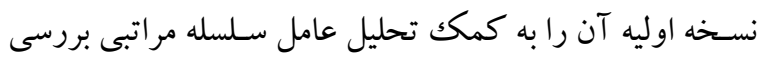

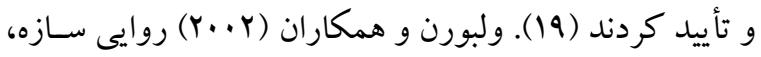
افتراقى، و همخراى اين ابزار را مناسب گزارش كردهاند ( (Y).

1. Schema short form of maladjustment 
تحويـل دهنــ. بـه منظور رعـايـت ملـاحظـات اخلاقى علاوه بر يافتهها به منظور بررسى فرضيه ئزوهش (بين روانبنه هاى سازشنايافته توضسيح هدف ئزوهش در دسـتور العمل همر اه ابزارها، هنگًام

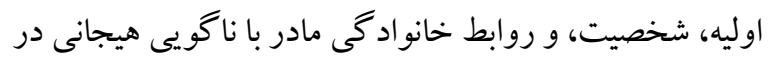

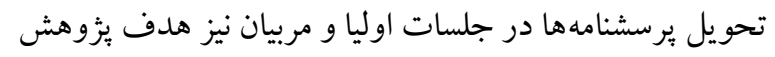

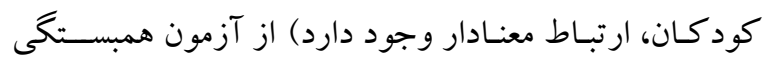
توضيح داده شد. همجنين اصل محرمانه بودن نتايج نيز رعايت

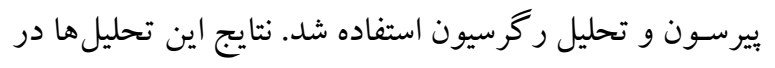

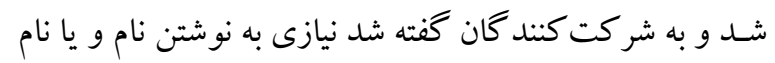
جدول اوب كزارش شده است.

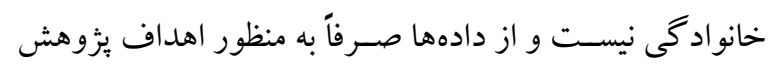
استفاده مى شود و در نهايت خاطر نشان شد كه دادهها به شكل كروهى و نه فردى تحليل مى شوند.

\begin{tabular}{|c|c|c|}
\hline معنادارى & ناتويى هيجانى كودكى & متغير هاى پيشيين \\
\hline.$/ .1$ & $\cdot / T F \mid$ & حيطه بريدگى و طردمادر \\
\hline.. .1 &.$/ r F V$ & حيطه خود كر دانى و عملكرد مختل مادر \\
\hline.$/ .1$ & . & حيطه محدوديت مختل مادر \\
\hline.$/ 11$ &.$/ 1 \Delta r$ & حيطه ديخر جهت مندى مادر \\
\hline.$/ .1$ & $\cdot / 49$. & حيطه كوش به زنخى بيش از حد و مهار مادر \\
\hline$\cdot / \cdot 4$ & $\cdot / \cdot \Lambda \Delta$ & آزردهخويى مادر \\
\hline$\cdot / 4+1$ &.$- / .1$ & برون گرايى مادر \\
\hline$\cdot / r$. &.$- / \cdot v a$ & تجربه كرا يى مادر \\
\hline - / Fro &.$/ .14$ & توافقيذيرى مادر \\
\hline$\cdot / 149$ &.$- / \cdot v v$ & وظيفهشاسى مادر \\
\hline . &.$- / .1 v$ & روابط خانو ادگى مادر \\
\hline
\end{tabular}

مـادر، محدوديت مختل مادر، ديخر جهت مندى مادر، و حيطه

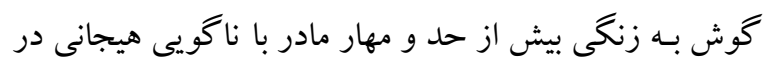

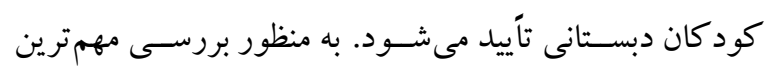

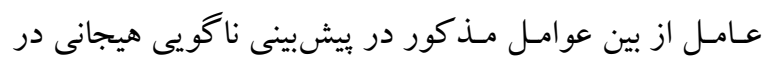
كود كان دبستانى از تحليل رگرسـيون كامبه كام استفاده شـد.

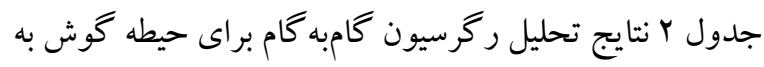
زنكى بيش از حسد و مهار مادر و حيطه خود كردانى و عملكرد

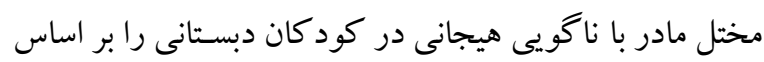
متغير هاى بيش بين نشان مى دهد.
يافتهاى جدول انشـان مى دهد كه حيطه بريدگى و طرد

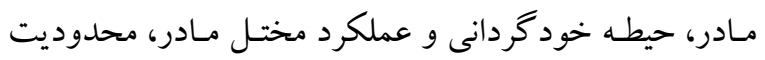

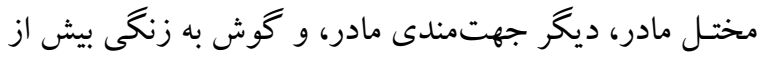

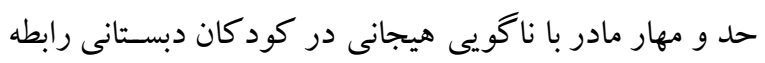

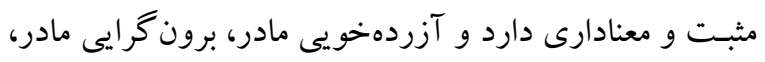

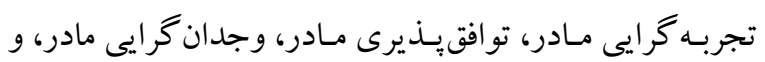
روابط خانوادگى مادر با ناكويى هيجانى در كود كان دبسـتانى مرانى رابطه معنادارى ندارد. به اين ترتيب اين فرضيه در بخش ارتباط

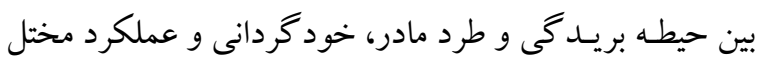


جدول r: تحليل ركر سيون كام به كام جهت ييشبينى ناكويى هيجانى در كود كان دبستانى بر مبناى حيطه كوش به زنكى بيش از حد و مهار مادر و حيطه خود رودانى و عملكرد مختل مادر

\begin{tabular}{|c|c|c|c|c|c|c|c|c|}
\hline 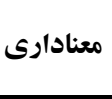 & آزادى درجه & آزادى & $\mathbf{F}$ & سهم خالص & رجذرور ضريب & رَر ريبون & متغير هاى وارد شده به معادله & كام \\
\hline.. .1 & ria & 1 & $10 / \wedge 91$ & .1 .91 & .1 .91 & $\cdot / 49$ & حيطه كوش به زنغى بيش از حد و مهار مادر & 1 \\
\hline . $/ 4 r$ & YM & 1 & $14 / 190$ &.$/ 11$ & $\cdot / \wedge \Delta$ & . Trar & حيطه خود گردانى و عملكرد مختل مادر & r \\
\hline
\end{tabular}

وارد معادله رگرسيون شده و اين متغير در كنار حيطه گُش به

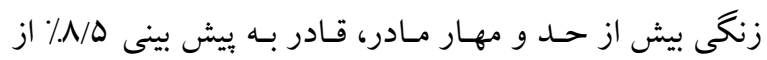

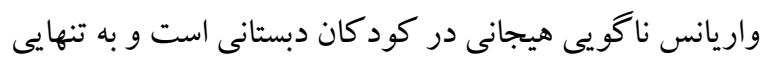
مى توانــ 1/1/ از واريـانس نـاكويى هيجـانى در كودكـان

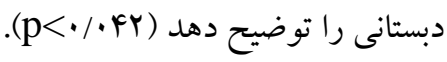

همان طور كه در جدول Y ملاحظه مىشود از بين متغيرهاى

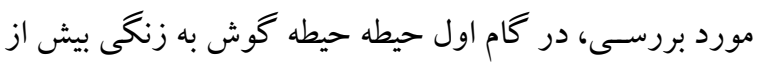

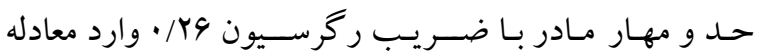
ركرسـيون شـده و قادر به بيش بينى /1/ از واريانس ناكويى

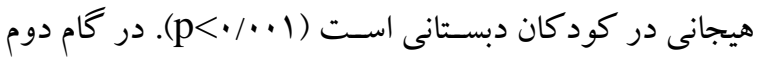

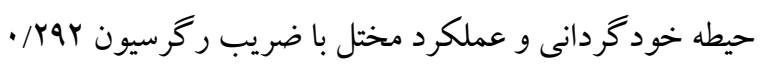

جدول س: تحليل واريانس يكى راهل جهت ارزيابى معنادارى سهم حيطه كوش به زنكى بيش از حد و مهار مادر و حيطه خود دردانى و عملكرد مختل

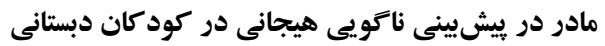

\begin{tabular}{|c|c|c|c|c|c|c|}
\hline معنادارى & $\mathbf{F}$ & ميانكين مجذورات & آزادى درجه & مجذوروات & تعداد & متغير \\
\hline$\cdot / \cdot \cdot 1$ & $10 / \wedge 91$ & $\begin{array}{l}\text { IORVN/TDF } \\
99 V / V F \text {. }\end{array}$ & $\begin{array}{l}1 \\
r / 9 \\
r r .\end{array}$ & $\begin{array}{l}\text { IOTVA/TDF } \\
\text { rIIQTYF/QQF } \\
\text { rYVTIT/MFA }\end{array}$ & باقيمانده & حيطه گوش به زنغلى بيش از حد و \\
\hline$\cdot / \cdot \cdot 1$ & $1 . / 109$ & $\begin{array}{l}Q 9 \wedge Q / A r r \\
Q \Delta R / A Y F\end{array}$ & $\begin{array}{l}r \\
r M \\
r r .\end{array}$ & $\begin{array}{l}\text { larVQ/994 } \\
\text { r.VQMT/9Nr } \\
\text { rrVHIT/MFA }\end{array}$ & باقيمانده & حيطه خود گردانى و عملكرد مختل \\
\hline
\end{tabular}

ناكويى هيجانى در كود كان دبستانى را بر اسـاس حيطه گوش بـه زنخگى بيش از حسد و مهار و حيطه خود گردانى و عملكرد مختل مادر را نشان مىدهد.
همانطور كه ملاحظه مى شـود سهم هاى بيش بينى شده در هر مرحلـه از لحـاظ آمـارى معنـاداربوده و قابل اعتماد اســت

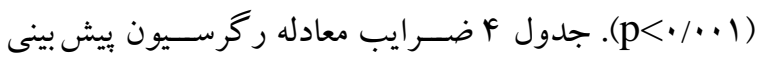

جدول ع: ضرايب خام و استاندارد معادله ركرسيون جهت يِي بينى ناكويى هيجانى در كود كان دبستانى بر اساس حيطه كوش به زنكى بيش از حد و

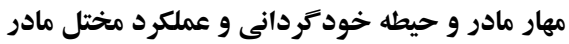

\begin{tabular}{|c|c|c|c|c|c|}
\hline معنادارى & $\mathrm{T}$ & ضريب بتا & خطاى استاندارد & ضريب خام(B) & متغير \\
\hline$\% \cdot 1$ & G/AVY & - & V/rar & $9 q / q 1$. & مقدار ثابت \\
\hline.$/ .1 \mathrm{~V}$ & $\cdot / 799$ & . /Ar &.$/ 499$ & .1949 & حيطه گوش به زنكى بيش از حد و مهار \\
\hline$\%$ Fr & אחו/. &.$/ 1 \Delta F$ & ת & $\cdot / T V Y$ & حيطه خود گردانى و عملكرد مختل مادر \\
\hline
\end{tabular}


جمله مى توان به يُزوهش هاى آزمايشى اشاره كرد كه با بهبود

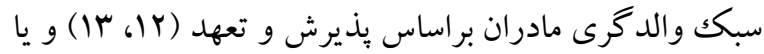

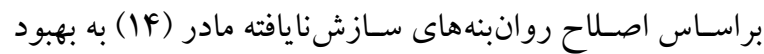

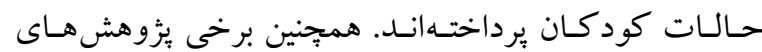

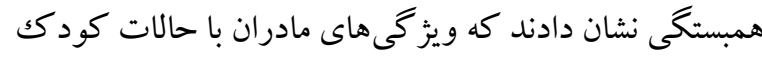
رابطه دارد؛ براى مثال رابطه خردمندى مادر با كاهش اختلالات رفتارى كود كان (ها) و يا رابطه معنادار و منفى بخشش مادر با مال

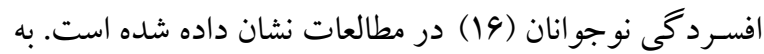

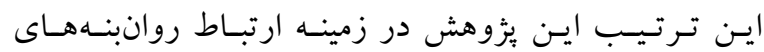

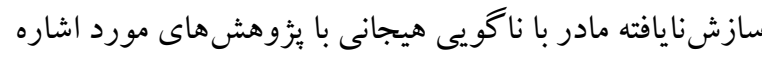

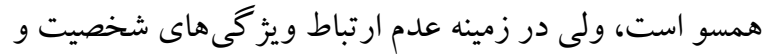
ارتبـاطـات خـانوادگى مادر با ناكويى هيجانى كود كك با نتايج اين بثزوهش ها ناهمسو است.

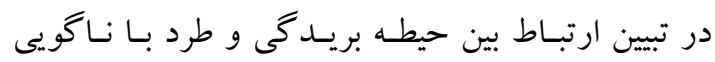

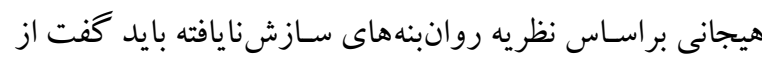

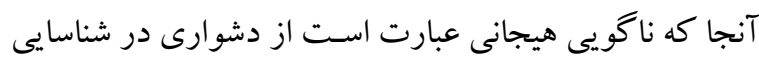
احسـاسـات، دشـوارى در توصـيف احسـاسات، و دشوارى در

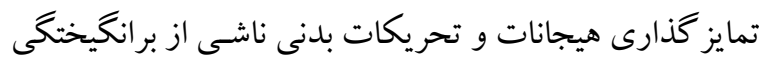

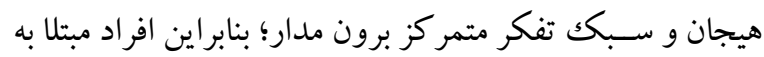

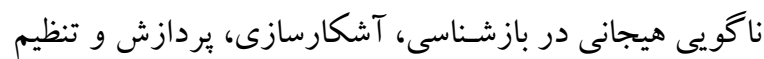
هيجانات مشكل دارند و قابليت تفكيك بين احساسات درونى دئى داسي از احسـاسـات بدنى را ندارند (YY، YY). از سـوى ديخر به نظر مىرســد مـادرى كـه در حيطه بريدگى و طرد دار ایى روانبنه

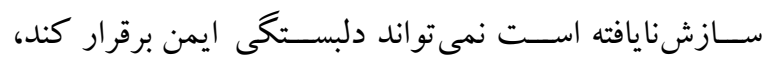

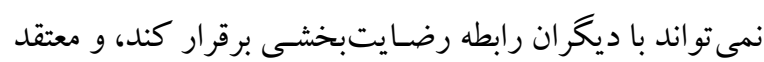
اسـت كه نياز آنها به ثبات، امنيت، محبت، عشق، و تعلق خاطر لفر بر آورده نخواهد شـــ. جنين مادرى كه معمولا خودش دوران كودكى تكاندهندهاى داشته است، از برقرارى روابط نزديك إنى

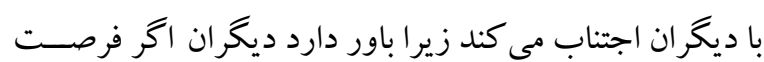

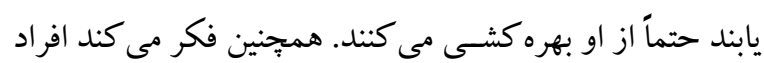

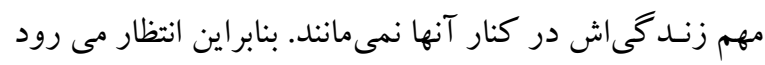

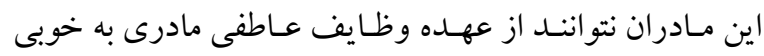

همان طور كه در جدول F ملاحظه مى شود، ضرايب خام و استاندارد بيش بينى معادله ناكويى هيجانى در كود كان بر مبناى

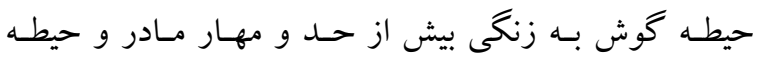

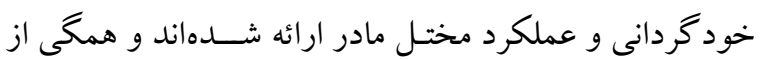

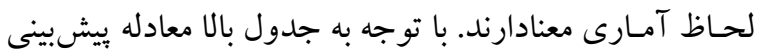

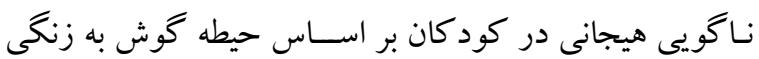
بيش از حسد و مهار مادر و حيطه خود گردانى و عملكرد مختل مادر به شرح زير است:

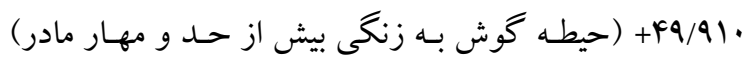

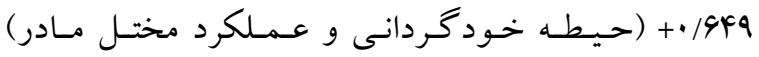

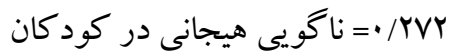

\section{بحث و نتيجه كيرى} يُزوهش حاضر با هدف بررسى روابط جند گُانه بين روانبنه هاى

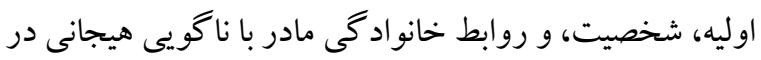

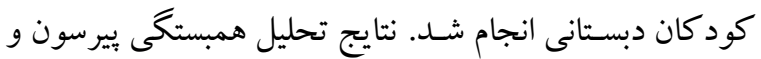
روش كامبه گام براى بررسى فرضيه يُزوهش نشان داد كه حيطه

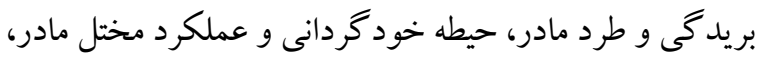

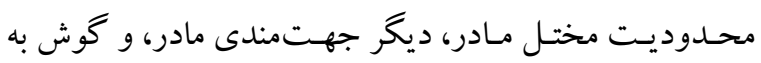
زنخى بيش از حد و مهار مادر با ناكويى هيجانى در كود كان دبســـانى رابطه مثبـت و معنادارى دارد و آزردهخويى مادر،

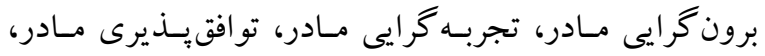

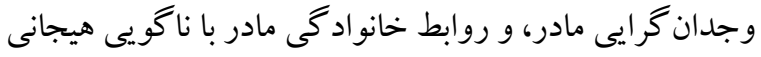
در كود كـان دبسـتانى رابطه معنادارى ندارد. با توجه به نتايج

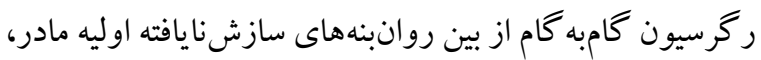
تنها حيطه هاى گوش به زنكى بيش از حد و مهار، خود گردانى،

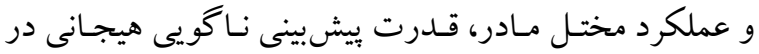

$$
\text { كود كان دبستانى را داشتند. }
$$

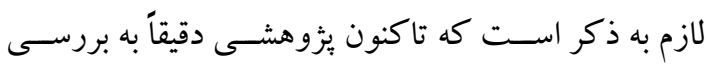

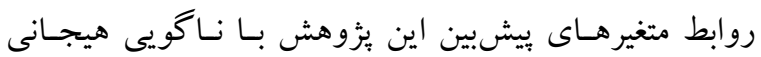
نبرداخته اســت اما برخى يزوهشها به بـ رابطه حالات مادر و يا

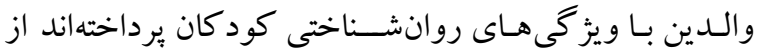


قـائل هسـتـن (19). مادرانى كه اين روانبنه را دارند، خود را نسـبــت بـه رعـايــت احترام متقابل كه پِيه و اســاس تعاملات

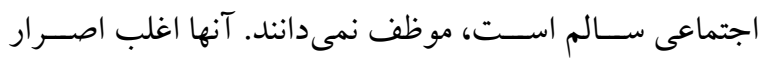
مى كنند كه مى توانند هر كارى را كه دلشــان بخو اهد، بدون

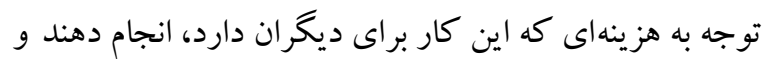
براى ارضـاى تمايلات خود سعى در سلطه گرى و مهار ديخران دارند. عدم ابراز محبت و برونريزى از ديخر خصـوصيات اين

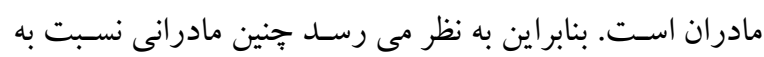

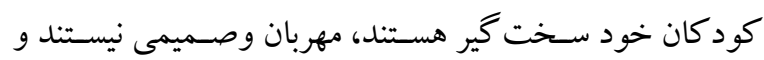

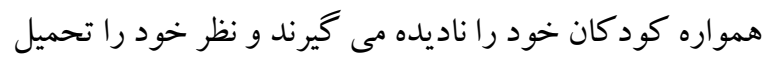
مى كنند. در نتيجه انتظار مىرود اين مادران نيز نتوانند از عهلده

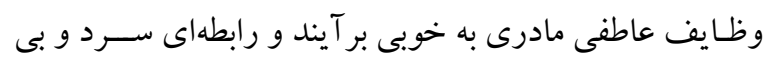

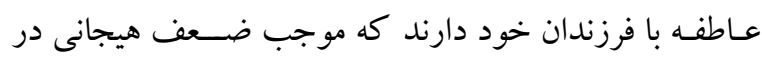
كودكـان آنها مى شــود و در نهايـت اين روانبنه با تغيرات ناكويى هيجانى رابطه دارد (ه).

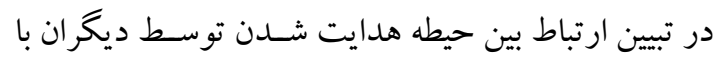
ناكويى هيجانى بايد گفت جنين مادرانى به جاى رسـيدگى به

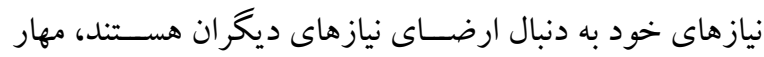
خود را به دسـت ديخران مىســــارند و در برابر آنها تسـليم مىشـوند، زيرا احساس مى كنند از اين طريق حرمت خود آنها زياد مى شود و مجبور هستند اين كار را انجام دهند. اين مادران همجينين نيازها و احساسات خود را مهم و ارزشمند نمى دانند، نيازهاى ديخران را با ميل خود و حتى به قيمت از دسـت دادن وادن رضايتمندى شخصى، ارضا مى كنند، دستيابى به تأييد و توجه

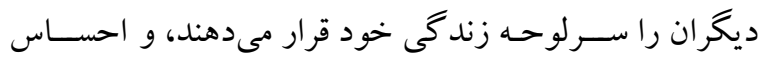
ارزشمند بودن خود را بيشتر به واكنش ديخران وابسته مى دانند تا واكنش هاى خودشــان (9). جنين مادرانى بيشـتر به ديخران اهميـت مىدهنـــ تـا فرزنـدان خود و در مورد موقعيـت هـاى مختلف هيجانى صسحبت نمى كنند، بنابر اين انتظار مىرود آنها

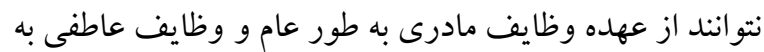

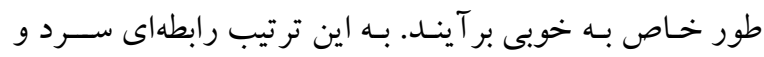

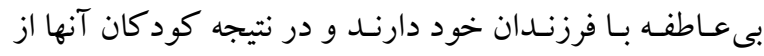

بر آيند و بدين ترتيب رابطهاى سرد و بى عاطفه با فرزندان خود دارند كه موجب ضــعف هيجانى در كود كان آنها مى شـــود و

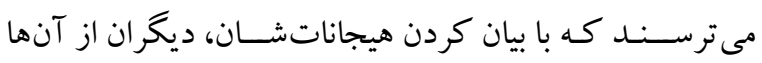

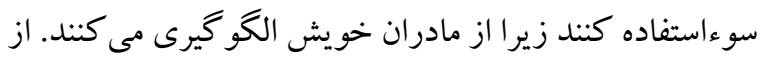
سـوى ديخر ممكن است روانبنه هاى اين زنان ريشه در عوامل كئل ززنتيكى داشـته باشـــ كه باعث سـردى هيجانى آنها شــده و در نتيجه منجر به شـكل گيرى روانبنه طرد شده است. اين سردى

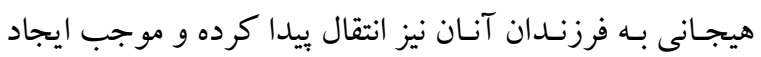
علائم ناگويى هيجانى در فرزندان آنان شده است.

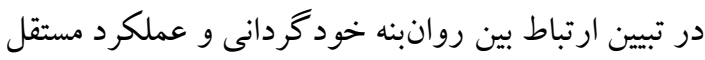

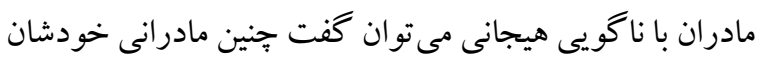
را افرادى درمانده و كود ككوار نشان مى مهندكه از عهده امور

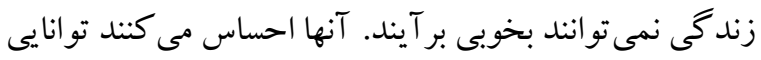

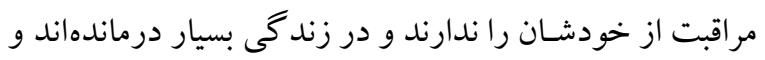
خود را در مقـابـل با مشــكلات و ديخران، بـى كفايت مىبيند.

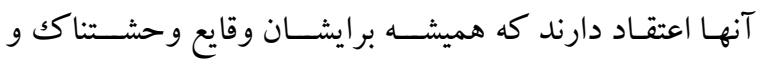

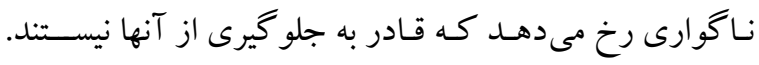

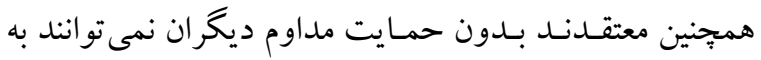

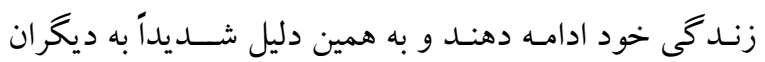
نيازمندند و در زندگى بى هويت و بى هدف هستند و اصطلاحا از حـال خود غـافل مىشـــند (9). بنابر اين انتظارمىرود اين مـادران نتوانند از عهده وظايف عاطفى مادرى به خوبى بر آيند و كود كانى تربيت كنند كه از لحاظ عاطفى مستقل وجرئت مند باشـند. از اين رو كود كان آنها به دليل اعتماد به خود يايين از بيان كردن عواطف شان در جمع شرمنده و خجالت زده هستند كه اين امر موجب ضعف هيجانى در آنها مىشود. در تبيين ارتباط بين حيطه عملكرد مختل با ناكويى هيجانى

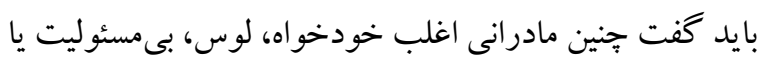

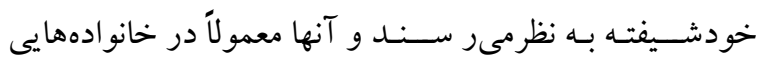

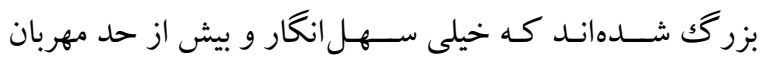
بودهاند. آنها خودشــان را يكك سـر و گردن بالاتر از ديخران مى دانند و در نتيجه حقوق و امتيازات خاصسى براى خودشــان 
(1) حضــور متغير هاى ميانجى و تعديل گرى كه رابطه اين دو

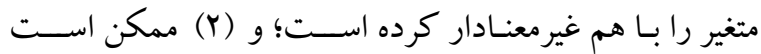

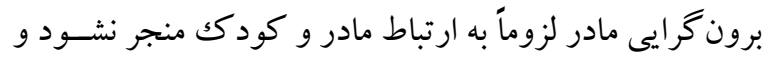

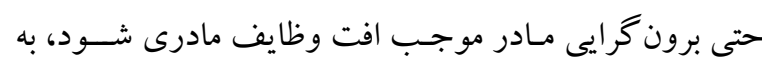

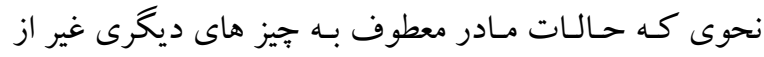
ارتبـاط بـا كود كش بــاشــــــــهـ طورى كـه به طور كل ارتباط برون گرايى با نا كويى هيجانى خنثى شود.

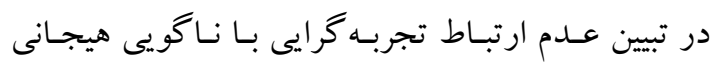
مى توان گفـت از آن جـا كـه در تجربـهـ گرايى، مـادر به دنبال

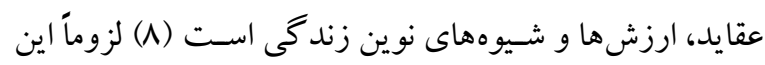
حالت مادر با حالات هيجانى كود كش ارتباط ندارد و در واقع تجربه گر ايى يك متغير نغرشسى به زندگى به حسـاب مى آيد؛

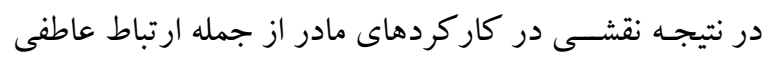

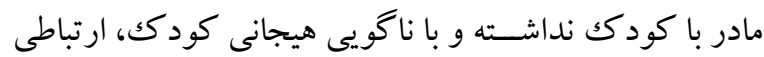

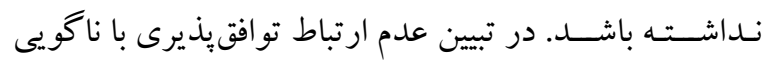

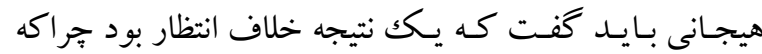
توافق يذيرى گر ايش هاى كنار آمدن و بيروى از ديخران رادر

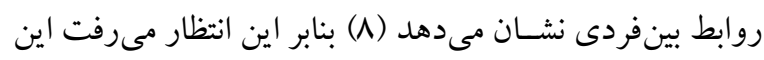
مادران در روابط بين فردى از جمله رابطه عاطفى با فرزندانشان

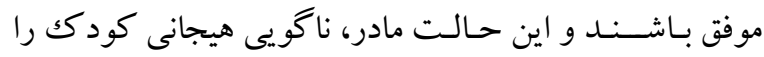
كاهش دهد اما اين نتيجه نشـان مى دهد كه متغير هاى ديخرى به غير از اين متغير در شكل گيرى ناگو دهيى هيجانى نتش دارند. در تبيين عدم ارتباط وجدان گرايى با ناگويى هيجانى بايد

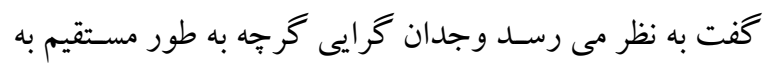

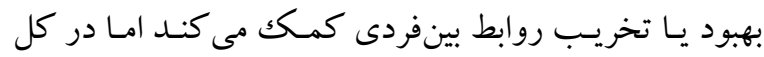

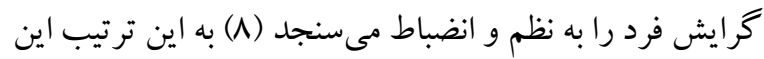

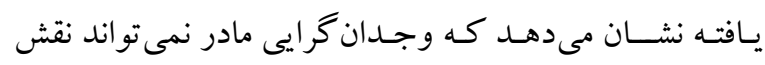

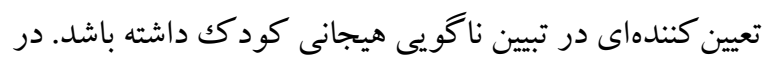

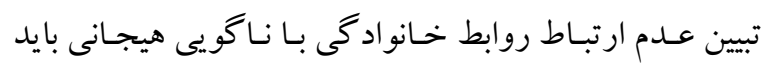

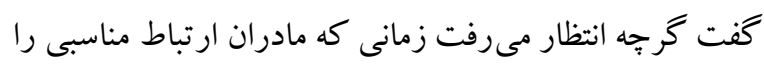

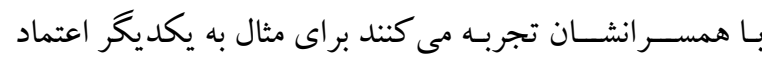

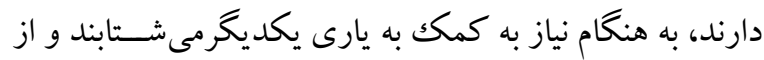

آكاهى مناسـب هيجانى برخور دار نيسـتند و به طبع نمى توانند

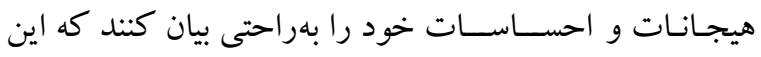
موجب ضعف هيجانى در آنها مى شود.

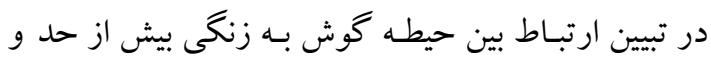

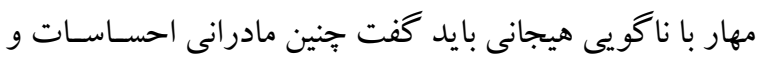

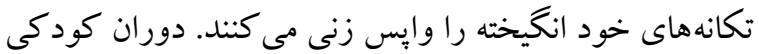

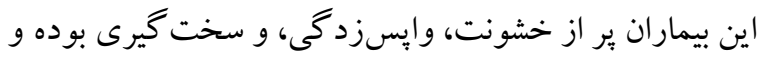

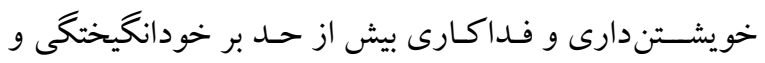

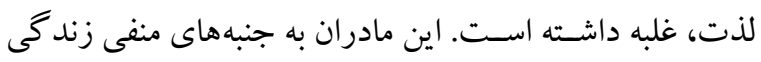

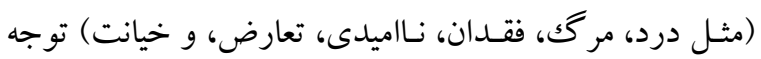
زيادى مى كنند، در حالى كه جنبه هاى مثبت را كمارزش جلوه مى دهند. رفتارها، احساسات و روابط بين فردى خودانگيخته شان

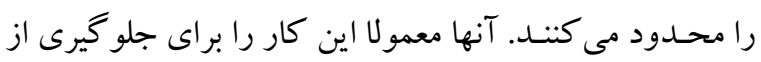
مورد انتقاد واقع شدن يا از دست دادن مهار روى تكانه هاىشان،

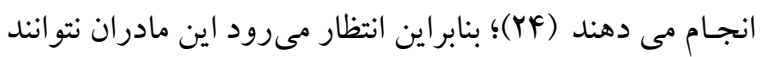

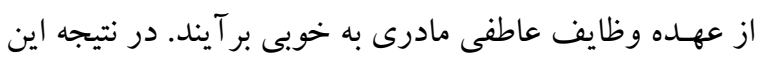

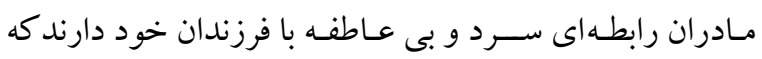
موجب ضعف هيجانى در كود كان آنها مى شود. در تبيين عدم ارتباط بين هنج عامل شخصيت مادر با ناكويى هيجانى مى توان

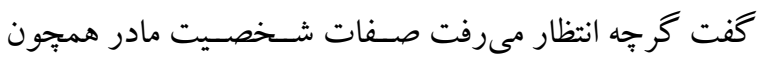

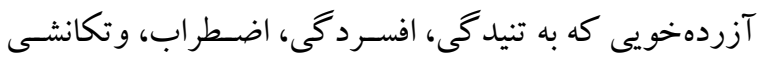

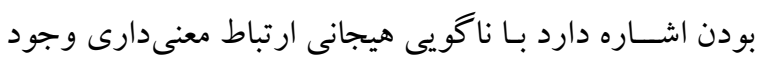
داشـهه باشـــ ولى اين ارتباط معنىدار نبود. به نظر مىرســ اين

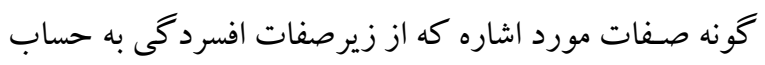

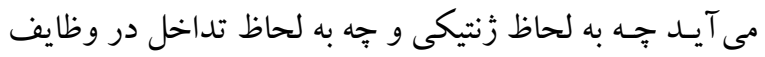

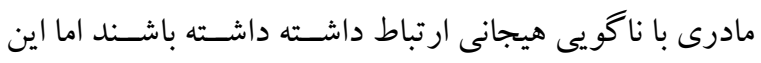

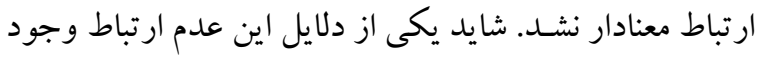

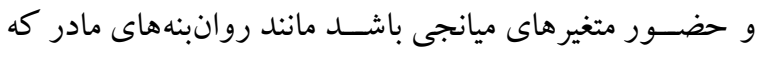

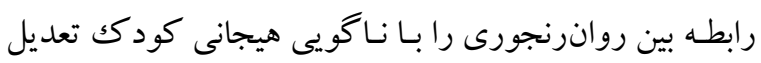

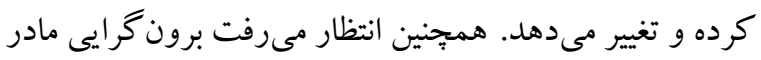
با كاهش ناكويى هيجانى كودك مرتبط باشــــ اما اين ارتباط

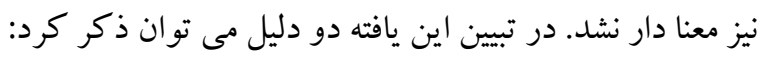


ساختارى استفاده كنند و يا براى تعيين نقش ميانجى متغيرها از

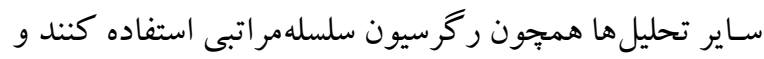
همجِين به منظور دستيابى به نتايج دقيق تر بيشنهاد مى شود ساير

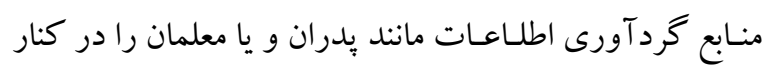
مادران مورد توجه قرار دهند.

تشـكر و قدردانى : اين يُزوهش بر گرفته از بايان نامه كارشــاسى ارشــ خانم الهام خليل الرحمن در رشـته روانشناسى بالينى دانشگاه

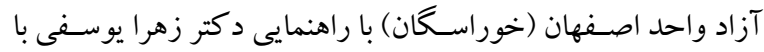

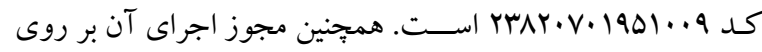
افراد نمونه از سوى اداره آموزشويرورش شهر اصفهان با شماره نامه

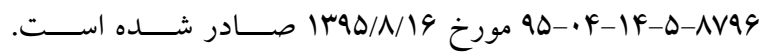

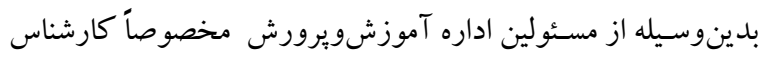

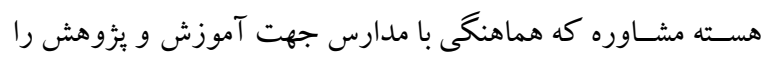

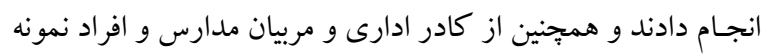
كه در اجراى اين طرح به ما كمكك كردند تشكر و قدردانى مىشود. تضـاد منافع: بدين وسـيله اعلام ميشـود كه اين مطالعه هيج گونه تضاد منافضى را براى نويسند كان نداشته است.
بودن با يكديخر لذت مىبرند (19)، محيط خانه امن باشد و در

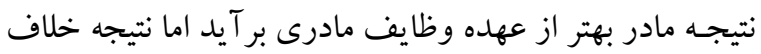

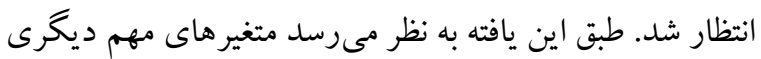

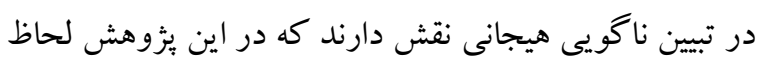
نشــده اسـت و يا متغيرهايى وجود دارد كه نقش ميانجى را بين

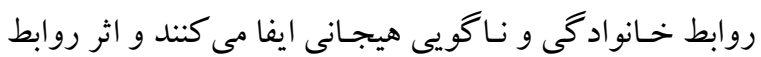

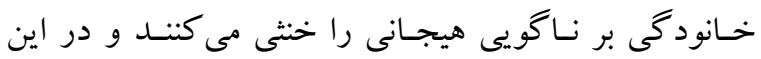
يثزوهش مورد بررسى قرار نكرفتند.

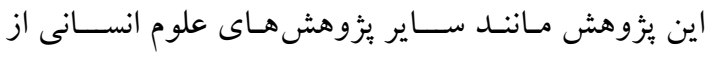

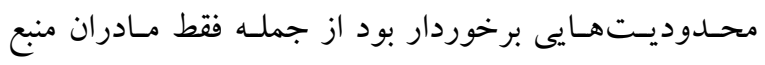
كردآورى اطلاعات بودند و نظرات كود كان ارزيابى نشـــند،

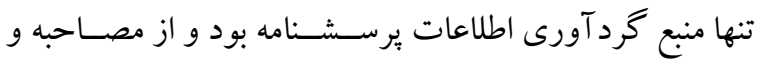

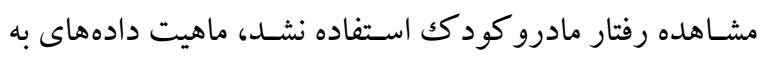

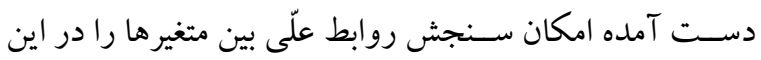

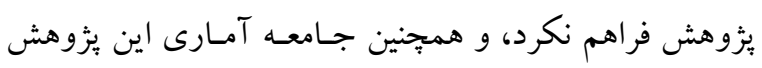
مادران دانش آموزان دبستانى شهر اصفهان بوده است كه امكان

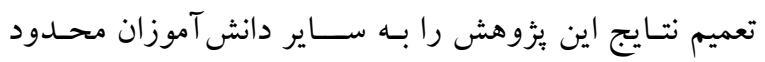
مى كند.

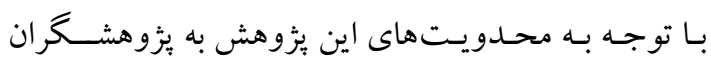

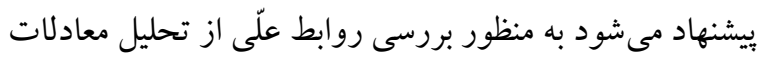




\section{References}

1. Sheppes G, Suri G, Gross JJ. Emotion regulation and psychopathology. Annu Rev Clin Psychol. 2015; 11: 379-405. [Link]

2. Yousefi, Z, Sobhani M. The effectiveness of quality of life therapy on burnout and it's dimensions among female workers. Quarterly Journal of Career \& Organizational Counseling. 2018; 10(4): 9-30. [Persian]. [Link]

3. Taylor GJ, Bagby RM, Kushner SC, Benoit D, Atkinson L. Alexithymia and adult attachment representations: associations with the five-factor model of personality and perceived relationship adjustment. Compr Psychiatry. 2014; 55(5): 1258-1268. [Link]

4. Hussain S, Ahmed Z. Parental acceptance-rejection as predictor of alexithymia among students in GilgitPaskistan. Int J Inf Educ Technol. 2014; 4(3): 285-288. [Link]

5. Costa AP, Steffgen G, Vögele C. The role of alexithymia in parent-child interaction and in the emotional ability of children with autism spectrum disorder. Autism Res. 2019; 12(3): 458-468. [Link]

6. Lyvers M, Mayer K, Needham K, Thorberg FA. Parental bonding, adult attachment, and theory of mind: A developmental model of alexithymia and alcohol-related risk. J Clin Psychol. 2019. [Link]

7. Ahmadimehr Z, Yousefi Z. Predicting adolescence depression: resiliency and family factors. SOP Transactions on Psychology. 2014; 1(2): 1-11. [Link]

8. Costa Jr PT, McCrae RR, Löckenhoff CE. Personality across the life span. Annu Rev Psychol. 2019; 70: 423-448. [Link]

9. Young JE, Klosko JS, Weishaar ME. Schema therapy: A practitioner's guide. Guilford Press, 2003. [Link]

10. Jafari F, Yousefi Z, Manshaee GR. Mothers Characters and adolescence depression. Open Journal of Depression. 2014; 3(2): 45-51. [Link]

11. Yousefi Z. Family functioning on the identity statues in high school boys in Isfahan, Iran. International Journal of Psychology and Counselling. 2012; 4(10): 127-135. [Link]

12. Yousefi Z, Homaie F. The effectiveness of mood improvement training based on acceptance and commitment on reducing depression and improving mothers' parenting styles in Zarinshahr. Journal of Jiroft University of Medical Sciences. 2018; 4(2): 236-248. [Persian]. [Link]

13. Salimi Souderjani M, Yousefi Z. The effectiveness of parenting styles training based on acceptance and commitment therapy (ACT) to mothers on decreasing sepration anxiety and oppositional defiant disorder of children. Journal of Child Mental Health. 2017; 4(2): 104-115. [Persian]. [Link]

14. Daneshmand khorasgani M, Yousefi Z. The effectiveness of group training of the reforming parenting styles based on mothers, maladjustment schemas on improving behavioral problems among preschool children in Isfahan city. Knowledge \& Research in Applied Psychology. 2018; 18(4): 62-71. [Persian]. [Link]

15. Pedramnia S, Yosefi Z. The relationship between wisdom dimensions and thought control strategies of mothers with symptoms of behavioral disorders in girls. Journal of Child Mental Health. 2018; 5(2): 131-141. [Persian]. [Link]

16. Barnes H. Parent-Adolescent communication. Family Inventories Used in a National Survey of Families across the Family Life Cycle. 1982; 33-46. [Link]

17. Shamaeizadeh N, Yousefi Z. Multiple relations between personality factors and history of child abuse with family communications in Isfahan. Knowledge \& Research in Applied Psychology. 2018; 19(3): 113-121. [Persian]. [Link]

18. Mojoudi M, Yousefi Z, Torkan H. Predicting the adolescence depression based on adolescence stress, resiliency, attachment style, and family relations among two groups of one-child and multi-child. Journal of Research in Behavioural Sciences. 2018; 16(2): 221-228. [Persian]. [Link]

19. Schmidt NB, Joiner TE, Young JE, Telch MJ. The schema questionnaire: Investigation of psychometric properties and the hierarchical structure of a measure of maladaptive schemas. Cognit Ther Res. 1995; 19(3): 295-321. [Link] 
20. Welburn K, Coristine M, Dagg P, Pontefract A, Jordan S. The schema questionnaire — short form: factor analysis and relationship between schemas and symptoms. Cognit Ther Res. 2002; 26(4): 519-530. [Link]

21. Sadooghi Z, Aguilar-Vafaie ME, Rasoulzadeh Tabatabaie K, Esfehanian N. Factor analysis of the young schema questionnaire-short form in a nonclinical Iranian sample. Iranian Journal of Psychiatry and Clinical Psychology. 2008; 14(2): 214-219. [Persian]. [Link]

22. McCrae RR, Costa PT, Martin TA. The NEO-PI-3: a more readable revised NEO personality inventory. J Pers Assess. 2005; 84(3): 261-270. [Link]

23. Anisi J. Validity and reliability of NEO Five-Factor Inventory (NEO-FFI) on university students. Journal of Behavioral Sciences. 2012; 5(4): 351-355. [Persian]. [Link]

24. McCrae RR, Costa PT. Validation of the five-factor model of personality across instruments and observers. J Pers Soc Psychol. 1987; 52(1): 81-90. [Link]

25. Joshanloo M, Daemi F, Bakhshi A, Nazemi S, Ghafari Z. Construct validity of NEO-personality inventory-revised in Iran. Iranian Journal of Psychiatry and Clinical Psychology. 2010; 16(3): 220-230. [Persian]. [Link] 